\title{
Body composition imaging
}

The assessment of body composition (BC) consists on the quantification and the study of the distribution of body elements at different levels (1). In this special issue, we will review what are the perspectives in the study of BC.

The first notions on the influence that the distribution of adipose tissue might have on the incidence of metabolic diseases were introduced in the 40's. In individuals that accumulated fat centrally, in the intra-abdominal and upper thoracic deposits, a close association with insulin resistance and a cluster of metabolic diseases was reported, whereas in individuals with a predominantly subcutaneous accumulation of the fat, in the femoral-gluteal region, the incidence of metabolic diseases, insulin resistance and dyslipidemia was significantly lower. These findings lead to the hypothesis that the accumulation of fat in specific locations could have a role on the association of adiposity with cardiometabolic risk. Out of the different adipose tissues, the visceral adipose tissue (VAT)—which is located around the organs, inside the abdomen and thorax — has been recognized as the one presenting a higher association with clinical and laboratory parameters characteristic of cardiovascular disease and metabolic syndrome. A number of studies have demonstrated that VAT has a metabolic activity, secrete inflammatory markers into the portal circulation, some with vasoactive properties that have a contributory effect on the development of cardiometabolic risk (2), whereas the subcutaneous adipose tissue (SAT) has been hypothesized to have different roles, from protective to more recently being associated to the development of insulin resistance, especially at abdominal level (3). The presence of lipids in other locations, such as the liver, skeletal muscle, bone marrow, have been associated with insulin resistance and adverse metabolic phenotypes, independently of total adiposity. These important associations have made the evaluation and quantification of specific adipose tissue compartments in the body of special importance. Several techniques are available to assess BC at each level of its complexity: atomic, molecular, cellular, organ-tissue and whole body (4). Whole-body, molecular, and organ tissue levels are the most investigated areas as a result of the availability of anthropometric methods and to the improved performance of the different available imaging techniques (5).

In this special issue, we will evaluate in depth what is the clinical impact of the study of BC, and review the methods to assess it. BC analysis was limited to research settings or selective clinical studies for a long time, due to the lack of available, acceptable, or accurate assessment tools other than the anthropometric measurements. Waist and hip circumferences, waist-to-hip ratio and body mass index (BMI) are the most common indexes used in clinical practice for the study of BC. These anthropometric data are easy to obtain and also cost-effective but their accuracy and reproducibility are limited, and they show poor or no correlation with VAT and SAT measurements obtained with the current gold standard imaging methods (6-8).

At the molecular level of assessment, bioelectrical impedance analysis (BIA), as a non-imaging technique, is commonly used, because of its improved accuracy and new technical features. Sarcopenia is defined as a syndrome characterized by progressive and generalized loss of skeletal muscle mass and strength by the European Working Group on Sarcopenia in Older People (EWGSOP). The decrease of muscle function (i.e., muscle strength or performance) is a requirement for the diagnosis (9). Sarcopenia is associated with many adverse outcomes. It increases morbidity and mortality, hospitalization rates, physical disability and results in loss of independence in activities of daily living (10). A dedicated article will focus on the assessment of sarcopenia (11). Today, due to the improved performance of some imaging techniques and the development of new methods, whole body, molecular, and organ tissue levels can be investigated in common clinical settings. BC clinical applications and opportunities have not been completely defined yet, and new developments are only just being transferred to every day practice (8).

Dual-energy X-ray Absorptiometry (DXA) is the reference method for BC assessment. This is the most widely used and validated imaging tool in current use. DXA measurements are based on a 3-compartment model that can be simplified into fat mass (FM), non-bone lean mass (LM) and bone mineral content (BMC). Body masses and bone mineral density $(\mathrm{BMD})$ can be assessed on a regional or a whole-body basis. DXA is reproducible, fast, relatively inexpensive, and involves very low radiation dose for the patient which make it ideal for clinical use and for longitudinal studies, in both adults and children (12,13). In a dedicated article, the advantages and new developments within this technique will be reviewed (14). Ultrasonography is a non-invasive, fast and relatively available and inexpensive alternative to estimate adiposity in clinical 
practice (15). It does not involve radiation, making it the ideal method for the evaluation of young people, and or large cohorts of patients. Conventionally, ultrasound has been assigned to the whole body and organ-tissue levels of assessment. Direct measurements of VAT and SAT thicknesses at different axial sections of the abdomen can be obtained, with good accuracy. But besides, it also allows an estimation of fat in terms of lipid content at both tissue and cellular-molecular level: it can measure adipose tissues as measurements of thickness, but it can also evaluate, in a few, intracellular fat content as variations in tissue echogenicity (16). In this issue, we will address the use of ultrasound in depth, from different perspectives: from the perspective of its possibilities in a dedicated article (17) and different population uses (for example its use in children). The gold standard techniques at organ-tissue level are Computed Tomography (CT) and Magnetic Resonance Imaging (MRI). They have excellent spatial resolution, allowing to obtain measurements on the composition of the different compartments, but also the analysis of intrinsic tissue composition (intracellular fat content). Their high cost, relatively low availability, elevated time consumption, and radiation exposure in the case of CT, have traditionally limited their use (15). In this special issue, we will analyze what are the safety standards for the assessment of BC (18) and what is the current and prospective use of advanced techniques (19).

In the field of research, $\mathrm{BC}$ has long been a hot topic for characterization of metabolic status (1) and investigations on $\mathrm{BC}$ have been focused on various population groups and diseases (e.g., obesity, diabetes, endocrine diseases, cancer) as well as physiological (growth, ageing processes) paraphysiological conditions (athletes—sports) or interventions (nutritional changes, diets) $(20,21)$. In this special issue, two articles will explore the specific topic of BC and renal disease (22) and bone tumors (23). Two different articles will focus on the impact on health status of the presence of lipids in specific organs and how imaging can unlock their assessment: the bone marrow (24) and the liver (25). A dedicated article will focus on the evaluation of BC in the paediatric population (26). Finally, we will evaluate what are the future perspectives in the analysis of BC, with the potential use of artificial intelligence and radiomics, in a dedicated article (27).

\section{Acknowledgments}

Funding: None.

\section{Footnote}

Provenance and Peer Review: This article was commissioned by the editorial office, Quantitative Imaging in Medicine and Surgery for the special issue "Body Composition Imaging". The article did not undergo external peer review.

Conflicts of Interest: Both authors have completed the ICMJE uniform disclosure form (available at http://dx.doi.org/10.21037/ qims-2019-bc-13). The special issue "Body Composition Imaging" was commissioned by the editorial office without any funding or sponsorship. GG served as the unpaid Guest Editor of the special issue and serves as an unpaid editorial board member of Quantitative Imaging in Medicine and Surgery. AB served as the unpaid Guest Editor of the special issue.

Open Access Statement: This is an Open Access article distributed in accordance with the Creative Commons AttributionNonCommercial-NoDerivs 4.0 International License (CC BY-NC-ND 4.0), which permits the non-commercial replication and distribution of the article with the strict proviso that no changes or edits are made and the original work is properly cited (including links to both the formal publication through the relevant DOI and the license). See: https://creativecommons.org/licenses/by-nc$\mathrm{nd} / 4.0 /$.

\section{References}

1. Thibault R, Genton L, Pichard C. Body composition: Why, when and for who? Clin Nutr 2012;31:435-47.

2. Fox CS, Massaro JM, Hoffmann U, Pou KM, Maurovich-Horvat P, Liu C-Y, Vasan RS, Murabito JM, Meigs JB, Cupples LA, D'Agostino RB Sr, O'Donnell CJ. Abdominal visceral and subcutaneous adipose tissue compartments: association with metabolic risk factors in the Framingham Heart Study. Circulation 2007;116:39-48. 
3. Patel P, Abate N. Role of subcutaneous adipose tissue in the pathogenesis of insulin resistance. J Obes 2013;2013:489187.

4. Wang ZM, Pierson RN, Heymsfield SB. The five-level model: a new approach to organizing body-composition research. Am J Clin Nutr 1992;56:19-28.

5. Lee SY, Gallagher D. Assessment methods in human body composition. Curr Opin Clin Nutr Metab Care 2008;11:566-72.

6. Busetto L, Baggio MB, Zurlo F, Carraro R, Digito M, Enzi G. Assessment of abdominal fat distribution in obese patients: anthropometry versus computerized tomography. Int J Obes Relat Metab Disord 1992;16:731-6.

7. Bazzocchi A, Diano D, Battista G. How fat is fat? Lancet 2012;380:e1.

8. Guerri S, Mercatelli D, Aparisi Gómez MP, Napoli A, Battista G, Guglielmi G, Bazzocchi A. Quantitative imaging techniques for the assessment of osteoporosis and sarcopenia. Quant Imaging Med Surg 2018;8:60-85.

9. Cruz-Jentoft AJ, Baeyens JP, Bauer JM, Boirie Y, Cederholm T, Landi F, Martin FC, Michel JP, Rolland Y, Schneider SM, Topinková E, Vandewoude M, Zamboni M. European Working Group on Sarcopenia in Older People. Sarcopenia: European consensus on definition and diagnosis: Report of the European Working Group on Sarcopenia in Older People. Age Ageing 2010;39:412-23.

10. Dennison EM, Sayer AA, Cooper C. Epidemiology of sarcopenia and insight into possible therapeutic targets. Nat Rev Rheumatol 2017;13:340-7.

11. Giraudo C, Cavaliere A, Lupi A, Guglielmi G, Quaia E. Established paths and new avenues: a review of the main radiological techniques for investigating sarcopenia. Quant Imaging Med Surg 2020. doi: 10.21037/qims.2019.12.15.

12. Toombs RJ, Ducher G, Shepherd JA, De Souza MJ. The impact of recent technological advances on the trueness and precision of DXA to assess body composition. Obesity (Silver Spring) 2012;20:30-9.

13. Leonard CM, Roza MA, Barr RD, Webber CE. Reproducibility of DXA measurements of bone mineral density and body composition in children. Pediatr Radiol 2009;39:148-54.

14. Messina C, Albano D, Gitto S, Tofanelli L, Bazzocchi A, Ulivieri FM, Guglielmi G, Sconfienza LM. Body composition with dual energy X-ray absorptiometry: from basics to new tools. Quant Imaging Med Surg 2020. doi: 10.21037/qims.2020.03.02.

15. Bazzocchi A, Filonzi G, Ponti F, Albisinni U, Guglielmi G, Battista G. Ultrasound: Which role in body composition? Eur J Radiol 2016;85:1469-80.

16. Bazzocchi A, Filonzi G, Ponti F, Amadori M, Sassi C, Salizzoni E, Albisinni U, Battista G. The role of ultrasonography in the evaluation of abdominal fat: analysis of technical and methodological issues. Acad Radiol 2013;20:1278-85.

17. Ponti F, De Cinque A, Fazio N, Napoli A, Guglielmi G, Bazzocchi A. Ultrasound imaging, a stethoscope for body composition assessment. Quant Imaging Med Surg 2020. doi: 10.21037/qims-19-1048.

18. Cornacchia S, La Tegola L, Maldera A, Pierpaoli E, Tupputi U, Ricatti G, Eusebi L, Salerno S, Guglielmi G. Radiation protection in non-ionizing and ionizing body composition assessment procedures. Quant Imaging Med Surg 2020. doi: 10.21037/qims-19-1035.

19. Huber FA, Del Grande F, Rizzo S, Guglielmi G, Guggenberger R. MRI in the assessment of adipose tissues and muscle composition: how to use it. Quant Imaging Med Surg 2020. doi: 10.21037/qims.2020.02.06.

20. Ponti F, Soverini V, Plazzi A, Aparisi Gómez MP, Mercatelli D, Guglielmi G, Battista G, Marchesini G, Bazzocchi A. DXAassessed changes in body composition in obese women following two different weight loss programs. Nutrition 2018;46:13-9.

21. Aparisi Gómez MP, Ponti F, Mercatelli D, Gasperini C, Napoli A, Battista G, Cariani S, Marchesini G, Bazzocchi A. Correlation between DXA and laboratory parameters in normal weight, overweight, and obese patients. Nutrition 2019;61:143-50.

22. Sabatino A, D'Alessandro C, Regolisti G, di Mario F, Guglielmi G, Bazzocchi A, Fiaccadori E. Muscle mass assessment in renal disease: the role of imaging techniques. Quant Imaging Med Surg 2020. doi: 10.21037/qims.2020.03.05.

23. Boutin RD, Katz JR, Chaudhari AJ, Yabes JG, Hirschbein JS, Nakache YP, Seibert JA, Lamba R, Fananapazir G, Canter RJ, Lenchik L. Association of adipose tissue and skeletal muscle metrics with overall survival and postoperative complications in soft tissue sarcoma patients: an opportunistic study using computed tomography. Quant Imaging Med Surg 2020. doi: 10.21037/ qims.2020.02.09.

24. Aparisi Gómez MP, Ayuso Benavent C, Simoni P, Aparisi F, Guglielmi G, Bazzocchi A. Fat and bone: the multiperspective analysis of a close relationship. Quant Imaging Med Surg 2020. doi: 10.21037/qims.2020.01.11.

25. Peng X, Li X, Xu Z, Wang L, Cai W, Yang S, Liao W, Cheng X. Age-related fatty infiltration of lumbar paraspinal muscles: a 
normative reference database study in 516 Chinese females. Quant Imaging Med Surg 2020. doi: 10.21037/qims-19-835.

26. Simoni P, Guglielmi R, Aparisi Gómez MP. Imaging of body composition in children. Quant Imaging Med Surg 2020. doi: 10.21037/qims.2020.04.06.

27. Attanasio S, Forte SM, Restante G, Gabelloni M, Guglielmi G, Neri E. Artificial intelligence, radiomics and other horizons in body composition assessment. Quant Imaging Med Surg 2020. doi: 10.21037/qims.2020.03.10.

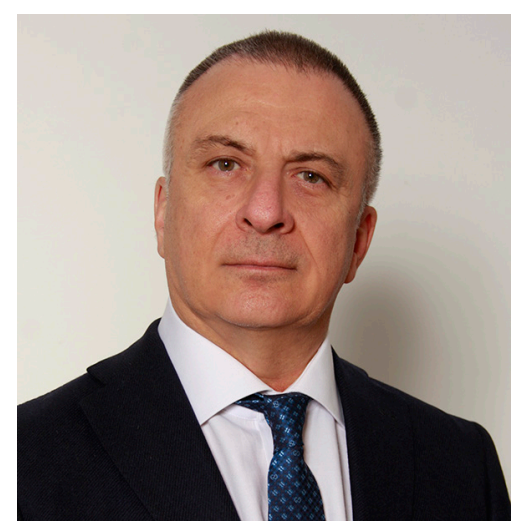

Giuseppe Guglielmi

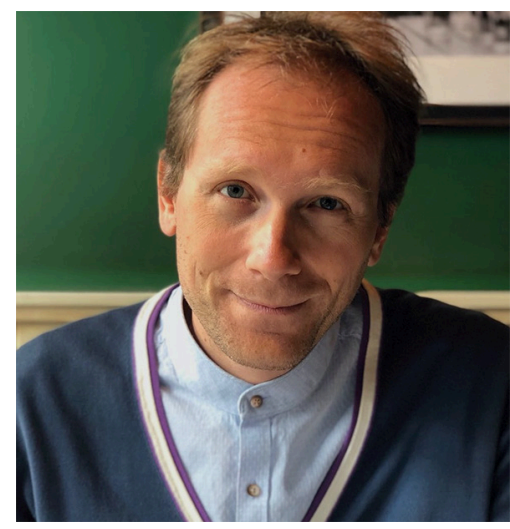

Alberto Bazzocchi

Giuseppe Guglielmi

Department of Radiology, University of Foggia, Foggia, Italy. (Email: giuseppe.guglielmi@unifg.it) Alberto Bazzocchi

Diagnostic and Interventional Radiology, IRCCS Istituto Ortopedico Rizzoli, Bologna, Italy. (Email: abazzo@inwind.it)

Submitted Jan 17, 2020. Accepted for publication Jun 15, 2020.

doi: 10.21037/qims-2019-bc-13

View this article at: http://dx.doi.org/10.21037/qims-2019-bc-13

Cite this article as: Guglielmi G, Bazzocchi A. Body composition imaging. Quant Imaging Med Surg 2020;10(8):15761579. doi: 10.21037/qims-2019-bc-13 